\title{
Frequency and risk factors of early tetany onset after thyroid gland surgery
}

\author{
Koko ADACHI ${ }^{* 1}$, Yu KAIHO*2, Kohkichi ANDOH ${ }^{* 1}$, \\ Satoshi SEKIGUCHI ${ }^{* 3}$, Yumiko SAKURADA ${ }^{* 1}$, Masanori YAMAUCHI ${ }^{* 4}$
}

\begin{abstract}
[Abstract] We aimed to clarify the risk factors for early postoperative tetany after thyroid surgery in order to facilitate perioperative management by anesthesiologists. We retrospectively investigated the frequency of tetany occurring within $24 \mathrm{~h}$ postoperatively in 564 patients who underwent thyroidectomy. We also performed a multivariate logistic regression analysis of its risk factors. The frequency of postoperative early tetany onset was $26 \%$ (149 cases), with its risk factors being as follows: young age [odds ratio(OR): 0.98 per year of age(95\% confidence interval(Cl): 0.96-0.99)], female sex [OR: $2.59(95 \% \mathrm{Cl}: 1.41-4.78)]$, operation time [OR: 1.31 per 60 mins(95\% Cl: $1.02-1.67)$ ], total thyroidectomy [OR: $2.31(95 \% \mathrm{Cl}: 1.49-3.58)$ ], and postoperative calcium(Ca)value [OR: 0.33 per $1 \mathrm{mg} / \mathrm{dL}(95 \% \mathrm{Cl}: 0.21-0.50)$ ]. Female patients, younger age, longer operation time, and total thyroidectomy factors can be used to prioritize postoperative management of patients with a high risk of postoperative tetany onset before postoperative $\mathrm{Ca}$ testing.

Key Words : Thyroidectomy, Tetany, Hypocalcemia, Early post-operative complication
\end{abstract}

\section{Background}

Tetany is caused by hypocalcemia, which manifests as numbness in the hands/feet and lips in mild cases, and as laryngospasms and seizures in severe cases. Numbness, which is a mild symptom, causes low patient satisfaction in the postoperative period. Several studies have been published on the occurrence of tetany beginning on the first day after thyroid surgery ${ }^{1,2)}$, but there is little information regarding tetany that occurs within $24 \mathrm{~h}$ postoperatively. To prevent the occurrence of tetany within $24 \mathrm{~h}$ postoperatively,

Received Sep. 4, 2019 ; Accepted Jan. 29, 2020

${ }^{* 1}$ Department of Anesthesiology, Sendai City Hospital

${ }^{*}$ Center for Simulation, Advanced Education and Innovation, The Children's Hospital of Philadelphia

${ }^{* 3}$ Department of Surgery, Sendai City Hospital

${ }^{* 4}$ Department of Anesthesiology and Perioperative Medicine,

Tohoku University Graduate School of Medicine even an anesthesiologist with no previous experience in tetany management could facilitate perioperative management of tetany through the administration of calcium $(\mathrm{Ca})$ during anesthesia. Therefore, our aim was to clarify the frequency and risk factors of early tetany onset postoperatively in order to assist anesthesiologists in the perioperative management of patients undergoing thyroid gland surgery.

\section{Methods}

This was a retrospective study of patients who underwent thyroidectomy under general anesthesia(to-

Corresponding author : Koko Adachi

Department of Anesthesiology, Sendai City Hospital

1-1-1 Asutonagamachi, Tihaku-ku, Sendai, Miyagi 982-8502, Japan 
tal thyroidectomy, subtotal thyroidectomy, or half thyroidectomy) at our hospital between November 2014 and September 2017 (Approval No. 477, Ethics Committee at our hospital). If the serum albumin value was $<4.0 \mathrm{~g} / \mathrm{dL}$, serum Ca was corrected for albumin using the following formula : Corrected serum $\mathrm{Ca}(\mathrm{mg} / \mathrm{dL})=$ measured total $\mathrm{Ca}(\mathrm{mg} / \mathrm{dL})+(4.0-$ serum albumin $(\mathrm{g} / \mathrm{dL}))$. Exclusion criteria included patients with an abnormal preoperative Ca level $(\leq 8.5$ $\mathrm{mg} / \mathrm{dL}$ and $\geq 10.4 \mathrm{mg} / \mathrm{dL}$ ), an American Society of Anesthesiologists physical status classification of 4 or above, previous thyroid gland surgery, thyroidectomy with a sternal midline incision, postoperative tracheostomy, or postoperative intensive care unit management. Dialysis patients and patients who underwent a second surgery within $24 \mathrm{~h}$ postoperatively were also excluded. Postoperative tetany was defined as a note in the patient's chart within $24 \mathrm{~h}$ postoperatively stating "tetany present" based on the nurses' 6-hourly postoperative questionnaire relating to tetany symptoms or the recording of tetany as absent or present. Pre- and postoperative serum $\mathrm{Ca}$ values were used, and the preoperative $\mathrm{Ca}$ value was obtained up to one month before surgery. The postoperative Ca value was measured on the first morning postoperatively. Ca gluconate $850 \mathrm{mg}$ was intravenously administered over $30 \mathrm{~min}$ if tetany appeared on the day of surgery. From the first day postoperatively, the need for supplementation is determined using the $\mathrm{Ca}$ value and the presence of symptoms, and patients are prescribed oral administration of $\mathrm{Ca}$ lactate and alphacalcidol. Data on factors related to the absence or presence of tetany such as preoperative diagnosis (Basedow disease, thyroid carcinoma, or adenocarcinoma), age, sex, height, weight, preoperative free triiodothyronine and thyroxine levels, operation time, anesthesia time, blood loss, infusion vol- ume, surgery type [total or non-total (subtotal or half resection)], and pre- and postoperative Ca values were extracted using a univariate logistic regression analysis $(P<0.10)$, and a multivariate logistic regression analysis was conducted $(\mathrm{P}<0.05)$. We used JMP Pro10 (SAS Institute Inc., Cary, NC, USA) for statistical analysis. Data are presented as median values(interquartile range).

\section{Results}

During the study period, 564 patients underwent thyroidectomy under general anesthesia with inhalation anesthesia through tracheal intubation or total IV anesthesia. Intraoperatively, patients received an IV infusion of crystalloid solutions. In addition, artificial colloid solutions or maintenance solutions were used as needed. Of the patients, $176(31 \%)$ had corrected Ca levels of less than $8.5 \mathrm{mg} / \mathrm{dL}$ on the first day postoperatively, while 149 (26\%) displayed symptoms of tetany within $24 \mathrm{~h}$ postoperatively. Univariate logistic regression analysis revealed significant differences in age, sex, preoperative diagnosis, surgery type, operation time, anesthesia time, blood loss, total urine volume, and postoperative corrected Ca value between patients with tetany and those without(Table 1). Multivariate logistic regression analysis of these factors, with the exception of anesthesia time, demonstrated that age, female sex, operation time, total thyroidectomy, and postoperative corrected $\mathrm{Ca}$ value were independent risk factors for tetany (Table 2).

\section{Discussion}

In the present study, tetany developed in $26 \%$ of patients within $24 \mathrm{~h}$ postoperatively. In previous reports, clinical symptomatic hypocalemia developed in $15 \%$ of patients on the first and second days after total-thyroidectomy ${ }^{2)}$ and in $28.7 \%$ of patients up to ap- 
Table 1 Clinical background characteristics

\begin{tabular}{|c|c|c|c|}
\hline & $\begin{array}{l}\text { Tetany group } \\
(\mathrm{n}=149)\end{array}$ & $\begin{array}{l}\text { Non-tetany group } \\
(n=415)\end{array}$ & $p$ value \\
\hline Age (year) & $43(35-55)$ & $46(36-62)$ & $0.003^{*}$ \\
\hline Gender (male/female) & $18 / 131$ & $91 / 324$ & $0.009^{*}$ \\
\hline Height (cm) & $158(154-163)$ & $159(154-165)$ & 0.21 \\
\hline Weight (kg) & $58(52-66)$ & $58(51-68)$ & 0.67 \\
\hline $\begin{array}{l}\text { Diagnosis } \\
\text { (Basedow disease/carcinoma/adenoma) }\end{array}$ & $51 / 92 / 6$ & $111 / 258 / 46$ & $0.018^{*}$ \\
\hline $\begin{array}{l}\text { Type of surgery } \\
\text { (Total thyroidectomy/Non-total thyroidectomy) }\end{array}$ & $95 / 54$ & $146 / 269$ & $<0.001^{*}$ \\
\hline Preoperative free triiodothyronine $(\mathrm{pg} / \mathrm{mL})$ & $2.99(2.7-3.3)$ & $2.88(2.67-3.19)$ & 0.31 \\
\hline Preoperative free thyroxine $(\mathrm{pg} / \mathrm{mL})$ & $1.03(0.91-1.15)$ & $1.03(0.93-1.12)$ & 0.92 \\
\hline Operative time (min) & $167(116-217)$ & $145(110-186)$ & $0.002^{*}$ \\
\hline Anesthesia time (min) & $212(158-269)$ & $190(153-233)$ & $0.004^{*}$ \\
\hline Blood loss (g) & $70(30-143)$ & $50(25-100)$ & $0.011^{*}$ \\
\hline Total urine volume $(\mathrm{mL})$ & $210(100-410)$ & $175(79-355)$ & $0.003^{*}$ \\
\hline Total infusion volume $(\mathrm{mL})$ & $1100(800-1350)$ & $1000(800-1300)$ & 0.35 \\
\hline Preoperative serum corrected calcium (mg/dL) & $8.9(8.7-9.2)$ & $8.9(8.7-9.4)$ & 0.39 \\
\hline Postoperative serum corrected calcium (mg/dL) & $7.8(7.4-8.3)$ & 8.3(7.9-8.6) & $<0.001^{*}$ \\
\hline
\end{tabular}

Table 2 Multivariate analysis of predictive risk factor for postoperative tetany

\begin{tabular}{llll}
\hline Factor & $\mathrm{OR}$ & $95 \% \mathrm{Cl}$ & $\mathrm{p}$ value \\
\hline Age (year) & 0.98 & $0.96,0.99$ & $0.003^{*}$ \\
Gender & 2.59 & $1.41,4.78$ & $0.001^{*}$ \\
Diagnosis (Basedow disease/carcinoma/adenoma) & $\dagger$ & $\dagger$ & 0.62 \\
Type of surgery & 2.31 & $1.49,3.58$ & $<0.001^{*}$ \\
$\quad$ Total thyroidectomy/Non-total thyroidectomy) & & & \\
Operative time (per 60min) & 1.31 & $1.02,1.67$ & $0.031^{*}$ \\
Blood loss (per 100g) & 0.96 & $0.74,1.25$ & 0.77 \\
Total urine volume (per 100mL) & 1.04 & $0.95,1.14$ & 0.40 \\
Postoperative serum corrected calcium (mg/dL) & 0.33 & $0.21,0.50$ & $<0.001^{*}$ \\
\hline
\end{tabular}

$\dagger$ Too few events for analysis

proximately 3 days after total and subtotal-thyroidectomy ${ }^{3)}$. To the best of our knowledge, this is the first report to show that the occurrence of tetany within $24 \mathrm{~h}$ postoperatively is nearly identical to its occurrence at a few days postoperatively.

Multivariate logistic regression analysis revealed that young age, female sex, prolonged operation time, total thyroidectomy, and lower postoperative $\mathrm{Ca}$ value were independent risk factors for tetany. The relationship between tetany and young age is unclear but may be related to easily detectable symptoms and unscheduled parathyroid resection with resultant hypocalcemia in young patients ${ }^{4), 5)}$. One report ${ }^{6)}$ asserted that postoperative tetany is common in females 
with Basedow disease. That report also suggested that hyperthyroidism is associated with hypocalcemia due to the sudden postoperative decline in parathormone levels and consequent rapid skeletal uptake of Ca. In the present study, no connection was observed between preoperative thyroid hormone values or Basedow disease and tetany onset, making it difficult to conclude that hyperthyroidism affects tetany onset. Total thyroidectomy was a risk factor for postoperative tetany. It can induce hypocalcemia caused either by resection or damage of multiple parathyroid glands, by blood dilution with an increase in urinary $\mathrm{Ca}$ excretion due to fluid therapy, or by elimination of calcitonin ${ }^{7)}$. Prolonged surgery was also a risk factor because it can cause hypocalcemia, as reported previously ${ }^{4), 6)}$.

The development of postoperative tetany indicated that younger aged female patients who underwent total thyroidectomy with a longer operation time had a high risk of tetany regardless of postoperative $\mathrm{Ca}$ testing. These patients require strict postoperative observation. Furthermore, because the frequency of early tetany onset (within $24 \mathrm{~h}$ postoperatively) was high, administration of preventative Ca supplementation during the anesthetic management period could have been considered.

This study had a few limitations. First, the presence of tetany was determined by each nurse, resulting in non-quantitative data. Second, it was not clear why young age and female sex were risk factors. Further investigation is necessary concerning the causes that increase the risk of tetany.

\section{Conclusions}

In this study, we found that the frequency of tetany within the early postoperative period was high (26\%), with the risk factors being female sex, younger age, and longer operation time among patients who underwent total thyroidectomy. Therefore, these findings can be used to prioritize postoperative management for patients with a high risk of postoperative tetany onset before postoperative Ca testing.

\section{References}

1) Pesce CE, Shiue Z, Tsai HL, et al. : Postoperative hypocalcemia after thyroidectomy for Graves' disease. Thyroid $20: 1279-1283,2010$

2) Eismontas V, Slepavicius A, Janusonis V, et al. : Predictors of postoperative hypocalcemia occurring after a total thyroidectomy : results of prospective multicenter study. BMC Surg $18: 55,2018$

3) Hosseini M, Otaghvar HA, Tizmaghz A, et al. : Evaluating the time interval for presenting the signs of hypocalcaemia after thyroidectomy. J Clin Diagn Res 10 : PC19PC22, 2016

4) Hallgrimsson P, Nordenström E, Almquist M, et al. : Risk factors for medically treated hypocalcemia after surgery for Graves' disease : a Swedish multicenter study of 1,157 patients. World J Surg 36 : 1933-1942, 2012

5) Sippel RS, Ozgül O, Hartig GK, et al. : Risks and consequences of incidental parathyroidectomy during thyroid resection. ANZ J Surg 77 : 33-36, 2007

6) Yamashita H, Noguchi S, Tahara K, et al. : Postoperative tetany in patients with Graves' disease : a risk factor analysis. Clin Endocrinol 47 : 71-77, 1997

7) Abboud B, Sargi Z, Akkam M, et al. : Risk factors for postthyroidectomy hypocalcemia. J Am Coll Surg 195 : 456-461, 2002 
甲状腺術後早期テタニー発生頻度とリスク因子

\author{
安達厚子*1, 海法 悠*2, 安藤幸吉*1, \\ 関口 悟*3, 櫻田幽美子*1, 山内正憲 ${ }^{* 4}$ \\ ${ }^{* 1}$ 仙台市立病院麻酔科 \\ ${ }^{* 2}$ Center for Simulation, Advanced Education and Innovation, The Children's Hospital of Philadelphia \\ *3 仙台市立病院外科 \\ ${ }^{* 4}$ 東北大学病院麻酔科
}

テタニーは甲状腺術後の主要な合併症であるが麻酔科医の認識は低い. 今回, 564症例の甲状腺術後 24時間以内の早期テタニー発生頻度とリスク因子を後ろ向きに調査した．術後早期テタニー発生頻度は $26 \%$ (149症例) であり，そのリスク因子は若年 [オッズ比 $(\mathrm{OR}): 0.98 /$ 年 $(95 \%$ 信頼区間 $(\mathrm{CI}): 0.96-0.99)]$, 女性 [OR:2.59 (95\% CI:1.41-4.78)], 手術時間 [OR:1.31/1時間 (95\% CI:1.02-1.67)], 甲状腺全摘 [OR: $2.31(95 \% \mathrm{CI}: 1.49-3.58)]$, 術後カルシウム $(\mathrm{Ca})$ 值 $[\mathrm{OR}: 0.33 / 1 \mathrm{mg} / \mathrm{dL}(95 \% \mathrm{CI}: 0.21-0.50)]$ であった. 女性, 若年, 長時間手術, 全摘術の症例はテタニー高リスクとして術後管理が必要であることが示唆さ れた.

キーワード : 甲状腺摘出術, テタニー, 低カルシウム, 術後早期合併症

The Journal of Japan Society for Clinical Anesthesia Vol.40 No.3, 2020 